\title{
New Evidences of Chinese Micro and Small Enterprises Financing: Capital Structures and Human Capitals
}

\author{
Sen Wang \\ Faculty of Economics, Shanxi University of Finance \& Economics \\ 696 Wucheng Lu, Taiyuan, Shanxi, 030006, China \\ E-mail: sen.wang@sohu.com \\ Jianjun Zou \\ College of Economics, Jinan University \\ 602 Huangpu DadaoXi, Guangzhou, Guangdong, 510632, China \\ E-mail: yeszou@126.com \\ Ning Zeng (Corresponding author) \\ International Business School, Jinan University \\ 206 Qianshan Lu, Zhuhai, Guangdong, 519070, China \\ Tel:+86-756-8505921Ｅ-mail: tningzeng@jnu.edu.cn
}

Received: October 27, 2015 Accepted: November 15, 2015

doi:10.5296/ber.v6i1.8491 URL: http://dx.doi.org/10.5296/ber.v6i1.8491

\begin{abstract}
This paper investigates a sample of 100 MSEs across Guangdong province in China through a questionnaire survey to examine capital structures at start-up and expansion stages and characteristics of business, and herein tests theories in the context of financial management. Our findings provide substantial support for the pecking order theory and the financial growth cycle model. Results also explore new evidences that human capitals play a vital role for MSEs' accessing to external financial resources, which should be considered in the financing modelling as an important determinant.
\end{abstract}

Keywords: Micro and small enterprises, Financing, Capital structures 


\section{Introduction}

Micro and small enterprises (MSEs) are those enterprises that employ not more than 250 employees and work on small scale, which contribute a major portion of country's gross domestic product (GDP) and economic activities as cross-country evidence shows (Beck et al 2003; Ayyagari, Demirgüç-Kunt and Maksimovic, 2006). In China, according to the report of State Administration for Industry \& Commerce (SAIC) and China Household Finance Survey (CHFS) in 2014, MSEs represent 94.15 per cent of the registered enterprises in the country and account for nearly half of China's GDP, 27.5 per cent of employment opportunities in cities and towns.

However, compared with large enterprises, MSEs are more constrained in their operation, growth, the taxation regime, market opportunities, and access to financial services. In particular, financing MSEs growth is one of the vital issues, which is explained by theories in the context of financial management practices. Terpstra and Olson (1993) pointed out that the difficulty of financing MSEs' startup and growth stages was caused primarily by the inadequate financial resources. As the theory of financial exclusion refers, MSEs are the sections of societies with constraints of accessing to mainstream financial services, such as modern payment instruments, consumer credit and insurance (Kempson and Whyley, 1999).

Also capital structure theories suggest, MSEs are normally owner-managed and mainly rely on private equity and debt markets to raise capital (Ang, 1991). According to Myers' (1984) pecking order model, firms have a particular preference order for their financing choices. In order to keep the original ownership and control of the firm intact, a firm would prefer inside finance to outside debt, short-term debt to long-term debt, and outside debt to outside equity. Therefore, the best financing pecking order of a firm would be inside finance, issuing debt, and then issuing equity (Barton and Gordon, 1987; Cassar and Holmes, 2003; and many others).

In the literature, Berger and Udell (1998) proposed a financial growth model for small-business capital structure. Their model depicts that small businesses have a financial growth cycle in which financial needs and options change as the firm starts-up, grows, gains further experience and becomes more transparent with its information. In the beginning, MSEs must rely on initial finance (for example, the owner, family or friends providing funds), trade credit and/or finance from a guardian angel. In the growth stage, firms may obtain intermediate finance (for example, venture capital and bank loans). As they continue to expand, firms may be able to gain access to public equity and debt markets.

Moreover, the life cycles of MSEs influence their capital structure decisions (Barton and Gordon, 1987; Dollinger, 1995; Poutziouris et al., 1996). Empirical evidences demonstrate that the firms' size has a positive influence on their capital structure (Jones, 1979; Titman and Wessels, 1988; Homaifar et al., 1994). Also Kimhi (1997) examines the relationship between capital structure and types of industry, and the results indicate that a high debt ratio exists in firms in some specific industries, such as the machine, food, medicine and electronic power industries. However, Norton $(1990,1991)$ suggested that these theories have very little relevance to capital structure decision-making in MSEs. 
While the issue of financing MSEs growth in China is particularly severe due to a unique economic progress. As the second economy in the world, state-owned enterprises (SOEs) and publicly listed companies dominate China's industrial landscape, which are privileged to be able to access financial resources. On the contrary, shareholders of MSEs find themselves are constrained to external funding (for example, long-term loans and venture capital), and financial expertise. Reforms regarding MSEs are required indeed, including financial services, enterprise development oriented toward industrial training, under-developed regulative bodies and law enforcement mechanism (Poutziouris et al., 2002). On this ground, Chinese authority announced the Law of Small and Medium Sized Enterprises in June 2002 to provide clearer legal responsibility, and to improve the approval process for guaranteeing loans to MSEs. Soon governments established credit guarantee agencies to assist MSEs fund raising from financial institutions. Yet, questions may still be remaining unanswered or new questions are emerging, which are concerned with the actual success of the government's initiative and the extent of the financial constraints that hinder MSEs expansion and growth.

This study aims to provide some descriptive and new evidence of MSEs financing in China. A questionnaire survey was carried out to a sample of 100 MSEs across Guangdong province in China to examine capital structures at start-up and expansion stages and characteristics of business, and herein test theories in the context of financial management practices such as financing pecking order. Our findings provide substantial support for the pecking order theory and the financial growth cycle model. Results also explore new evidences that human capitals play a vital role for MSEs' accessing to external financial resources, which should be added in the financing modelling as an important determinant.

This paper is organised as follows. Section two reviews MSEs financing in China, and MSEs capital structures and modeling are described in section three. Section four proceeds to present the results and discuss the findings. Finally section five concludes.

\section{MSEs Financing in China}

Since China launched its reform and opening-up drive in the late 1970s, the private sector has been acknowledged as an important part of China's economy. With China's joining WTO in 2001, MSEs have become the growth engine of China's fast growing economy (Poutziouris et al., 2002; Chen, 2006).

And yet there exists an unique banking system in China, which comprises of three policy banks, five state-owned commercial banks, twelve joint-stock commercial bank, and other city commercial banks, trust and investment corporations under supervisory bodies of The People's Bank of China (PBOC) and China Banking Regulatory Commission (CBRC) (CBRC, 2015). Major lenders at the top are state-owned banks, receiving generous financial support from the state and accounting for more than half per cent of total banking assets.

As a result the state actually plays an influential role in strategic, operational and managerial decisions (Park and Sehrt, 2001; Cousin, 2011). For example, large SOEs are likely to receive bank loans since they are unlikely to fail. If large SOEs are declared bankrupt, there is high possibility that they would be rescued or reformed by the state. Hence the risk attached to 


\section{Macrothink}

these bank loans are considered as being low, and lenders tend to grant loans to SOEs albeit large volumes of nonperforming loans, rather than MSEs to minimise default risk.

When MSEs submit their loan applications to banks, banks will normally investigate the information provided by the borrowers. However, there is a lack of credit registries for micro and small businesses in China. For the MSEs in need of bank loan, especially the early stages of their development, which means they are not in a shape of formal structure, good governance and collateral. Then banks follow a normal credit control procedure, which is, however, an obstacle for the MSEs since many banks only accept limited types of tangible fixed assets as collateral. A lack of assets limits the capacity of MSEs to obtain loan guarantees from the banks. For MSEs financing with banks in China, the truth is that a considerable processing time is required for a small amount loan.

To solve this issue, the Chinese Ministry of Finance in collaboration with other government sectors set up a MSE loan guarantee system in the beginning of 1999. This process has established more than 200 credit-guarantee institutions with a fund of 10 billion Yuan. Although MSEs contribute nearly half of China's GDP, they are not be granted to access to half of financial resources. As reported by CHFS' research in 2013 shown in figure 1, 42.2\% MSEs are reluctant to apply for loans at banks. Only 46.2\% MSEs apply for bank loans and succeed, and $11.6 \%$ of MSEs bank loans applications are rejected.

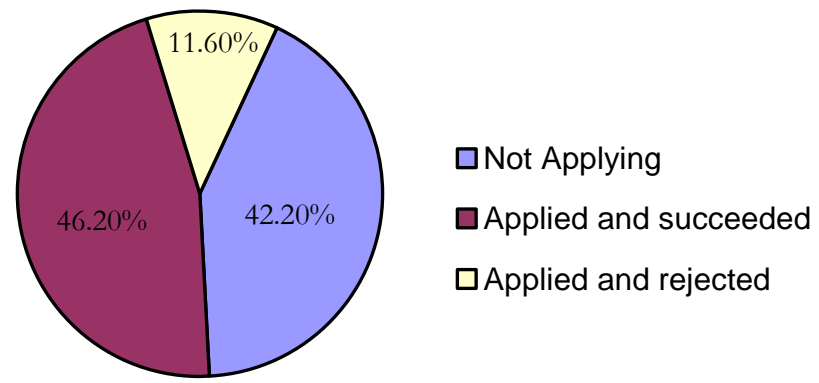

Figure 1. Bank loans of MSEs

Source: CHFS

For those MSEs, receiving bank loans, have gained a net profit of 43 million and created 1822 jobs for using each 100 million bank loan. While other corporations including state-owned enterprises and publicly listed companies, have merely obtained a net profit of 18 million and provided 231 jobs for using exactly the same 100 million bank loan. This allocation of financial resources to the least efficient corporations rather than most efficient private firms, illustrated in figure 2, also worsens the financial exclusion of MSEs' financing (Podpiera, 2006). Under the undeveloped finance system, the current MSE development boom in China might slow down without a long-term and unified strategy, and systematic governing policies (Wang 2004). 


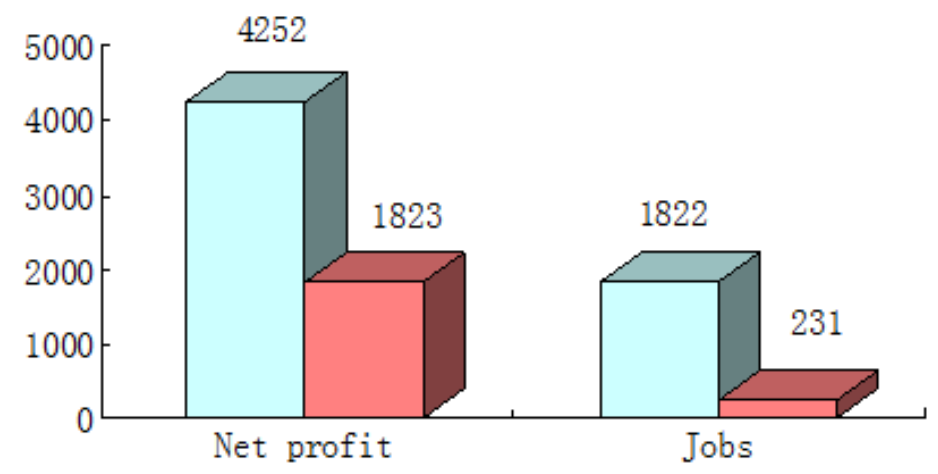

$\square$ MSES

$\checkmark$ State owned and public listed enterprises

Figure 2. The effectiveness of bank loan (per 100 million RMB)

Source: CHFS

\section{Capital Structure and MSE Financing Model}

\subsection{The Capital Structure of Mses}

In much empirical modelling research, theoretical constructs must be proxied via firms' variables such as size, asset structure, profitability, risk and growth. Because of the marginal effects of market access for different sized firms, high transaction costs may influence the decision making on available financing choices. Smaller firms are offered less capital or with significantly higher costs to larger firms, which discourage the use of outside financing. And smaller scale financing results in relatively higher transaction costs too (Titman and Wessels, 1988; Wald, 1999), which has effects on firms' financing options available outside. Also smaller firms have less outside financing or lower debt if the relative costs of bankruptcy are inversely related to firm size, affecting liquidation returns and businesses operating decisions (Titman and Wessels, 1988). If there is an inverse relation between operating risk and firm size, smaller firms would seek to use less debt and outside financing (Cosh and Hughes, 1994). In the long-run firms' size are positively associated with leverage, outside financing and bank financing. While a negative relationship exists between short-term liabilities and firm size (Osteryoung et al., 1992; Chittenden et al., 1996; Michaelas et al., 1999; Fluck et al., 1998).

It is also notable that asset structure is an important determinant of the capital structure of firm. The degree to which the firms' assets are tangible and generic would indicate a greater liquidation value (Titman and Wessels, 1988). With collateral assets, a fixed charge is directly placed to particular tangible assets of the firm, and hence it reduces adverse selection and moral hazard costs. Since bank financing depends on whether the lending can be secured by tangible assets (Berger and Udell, 1998), firms with assets that having greater liquidation value would be relatively easier excess to finance, and lower costs of financing. This leads firms to have a higher level of debt or outside financing in their capital structure. For large firms, asset structure and leverage are positively related. However, MSEs may have a positive relationship between asset structure and leverage, long-term debt, and probably a negative relationship with short-term debt (Chittenden et al., 1996; Jordan et al., 1998; Michaelas et al., 1999). 
And yet, firms normally have a preference for inside financing over outside financing, as the cost for outside capital should be greater. According to the pecking order hypothesis of Myers (1984), profitable firms, having access to retained profits, could use these for firms' financing rather than outside sources due to the information asymmetries between the firm and outsiders. And indeed more profitable firms, which are more likely to receive outside financial sources, would still prefer inside funds to finance their operations and investments. This suggests a negative relation between leverage and profitability in MSEs (Chittenden et al., 1996; Jordan et al., 1998; Michaelas et al., 1999).

Moreover, firms with relatively higher operating risk tend to have lower leverage than other more stable earnings firms. In a static framework model, firms may not to fully utilise the tax benefits of 100 per cent debt given agency and bankruptcy costs. The more likely a firm will be exposed to such costs, the greater their incentive to reduce their level of debt within the capital structure of the firm. Therefore, a positive relationship has been explore the between risk and leverage for MSEs (Jordan et al., 1998; Michaelas et al., 1999).

In addition, firms will place a greater demand on the internally generated funds at growing stage, which leads firms with higher growth to seek outside financing. As the pecking order hypothesis suggests, firms should seek a short-term less secured debt first, then a longer-term more secured debt for their financing needs. And thus firms with relatively higher growth will have more leverage. Given the firms' option to undertake growth opportunities in the future, Myers (1977) implies that conflicts between debt and equity holders are especially serious for assets, resulting in firms with such growth opportunities having less debt. On the contrary, Michaelas et al. (1999) argue that the agency problem and the costs of financing are reduced, and thus future growth opportunities are positively related to leverage. While Chittenden et al. (1996) and Jordan et al. (1998) found mixed evidence.

\subsection{The MSE Financing Model}

Based on the analysis above, Cassar and Holmes (2003) proposed a multivariate analysing framework to investigate the determinants of capital structure and use of financing for small and medium sized enterprises. They defined five capital structure and financing measures as dependent variables: leverage, long-term leverage, short-term leverage, outside financing and bank financing. Where leverage (LEV) is the total debt of the firm divided by the total assets; long-term leverage (LONG) is included with the obvious maturity and duration differences; and short-term leverage (SHOR) is the difference between leverage and long-term leverage. Then an outside financing (OUT) measure examines the influence of agency cost arguments upon financing choice. Particularly, a bank financing (BANK)) is advantageous to observe whether banks behave differently to 'other' outside financiers, such as a potentially greater reliance of assets in place for securing debt.

To accommodate independent variables, which are discussed in section 3.1, and dependent variables, the MSEs financing model is described as follows:

$$
\mathrm{Y}=\beta_{0}+\beta_{1} S I Z E+\beta_{2} N O N A+\beta_{3} R O A+\beta_{4} R I S K+\beta_{5} G R O W
$$




\section{Al Macrothink}

Business and Economic Research

ISSN 2162-4860

2016, Vol. 6, No. 1

where Y represents each dependent variable, SIZE is total assets, NONA means Non-current assets divided by total assets, ROA is return on assets before interest, RISK is coefficient of variation in profitability, and GROW is growth in sales. And this model empirically tests for each dependent variable, and the predicted sign for the coefficients with respect to leverage is displayed under each independent variable.

\section{Empirical Results}

\subsection{The Data}

The approach to this study involved gathering data through National Bureau of Statistics (NBS), Annual Reports of governments. Meanwhile an informal questionnaire survey was carried out with 100 MSEs via phone, email, website and interview across Guangdong province during the period of 2013-2015, where MSEs account for around 96\% of registered enterprises.

As table 1 displays, the MSEs are from various industries, such as manufacturing, investment, entertainment, high technology, catering, logistics, construction, wholesale and retail, which run businesses operating not only locally, but also national and globe wide and employ fewer than 100 employees. Those companies are at the start-up and expansion stage with owner or managers who are on average between 25 and 50 years of age and possess from low to high education qualifications.

Table 1. Data descriptives

\begin{tabular}{|c|c|c|c|}
\hline & Percentage(\%) & Ownership & Percentage(\%) \\
\hline Industry & & Collectively owned & 34.2 \\
\hline Manufacturing & 10.8 & Individually or family owned & 40.8 \\
\hline Investment & 3.6 & Share holding corporation & 25.0 \\
\hline Entertainment & 5.5 & Business scope & \\
\hline High technology & 10.2 & Local & 40.6 \\
\hline Catering & 17.9 & National & 55.2 \\
\hline Logistics & 16.6 & International & 4.2 \\
\hline Construction & 12.9 & & \\
\hline Wholesale and retail & 21.5 & & \\
\hline Others & 1.0 & Qualification of owners & \\
\hline & & < undergraduate & 40.6 \\
\hline Age of owners & & Undergraduate & 32.8 \\
\hline$<30$ & 6.6 & Postgraduate & 26.6 \\
\hline $30-49$ & 30.0 & & \\
\hline$>50$ & & & \\
\hline
\end{tabular}

Source: Annual Reports of Guangdong Province, Survey by authors.

\subsection{Results and Analysis}

One of the key questions in this study is the financial resources for MSEs start-up and 
growing. As shown in table 2, results demonstrate that the financial resources for the respondents at business are the owner's private savings, money borrowed from family and friends, bank loans and other funds. Notwithstanding bank loans to MSEs increase each year according to authorities' report, our findings suggest that less than $10 \%$ of MSEs receive bank loans for their star-ups whereas up to $17.6 \%$ for their expansions. This is inconsistent with previous surveys by the China Industrial and Commercial Union and the Research Commission of Chinese Private Business, which suggest that $65.5 \%$ of capital originated from self-accumulation, $21 \%$ from bank loans and $13.5 \%$ from friends, relatives and other individuals for MSEs financing during past two decades.

Table 2. Financial resources for MSEs

\begin{tabular}{|l|c|c|}
\hline \multirow{2}{*}{} & \multicolumn{2}{|c|}{ Stage } \\
\cline { 2 - 3 } & Start-up & Expansion \\
\hline Internal financing & 52.5 & 42.8 \\
\hline External financing & 38.9 & 39.6 \\
\hline Bank loan & 8.6 & 17.6 \\
\hline
\end{tabular}

Source: Annual Reports of Guangdong Province, Survey by authors.

Notes: Figures are in percentage $(\%)$.

Although the pecking order hypothesis suggests that the owners of firms would prefer internal rather than external finance, and debt rather than equity, due to reluctance of compromising their independence and control, the demand for external financing has increased sharply. Certainly the proportion of MSEs using external financing, that is nearly $40 \%$ in our survey is significantly higher than that in previous studies. The main reason of rising external financing is the booming of internet lending and borrowing business and other funds, which are more convenient than bank loans albeit more cost. In spite of improvements of MSEs' financing with Chinese banks, a fast track from internet financing are advantaged to swift decision making for business deal, and therefore fits MSEs' financial needs.

Table 3. External financing allocations for MSEs

\begin{tabular}{|l|c|c|}
\hline & Application & Succeed \\
\hline Characteristics & & \\
\hline Non-creative & 10.6 & 26.7 \\
\hline Creative & 89.4 & 1.6 \\
\hline Age of owners & & \\
\hline$<30$ & 15.9 & 1.2 \\
\hline $30-49$ & 70.2 & 25.2 \\
\hline$>50$ & 13.9 & 0.9 \\
\hline Qualification of owners & & \\
\hline$<$ undergraduate & 12.5 & 5.3 \\
\hline Undergraduate & 52.3 & 21.5 \\
\hline Postgraduate & 35.2 & 34.8 \\
\hline
\end{tabular}

Source: NBS, Annual Reports of Guangdong Province, Survey by authors.

Notes: As in table 2. 
Furthermore, external financing tend to be granted to MSEs business with creativity such as high technology and entertainment from the results presented in table 3. Since government and other institutions would like to attract young talents with high skills, a large amount of funds are provided to develop creative industry and eventually to stimulate economic growth. This is specifically the main financial resources for young and highly skilled talents overseas to bring new technology back in China. On the other hand, venture capitals also support creative industry to make profit. Together with internet financing, all of the external financing means are no obstacles for ownership. As previous studies suggest, the independence motive is critical to understanding the observed choices about the capital structure of small businesses. So that, when businesses expand, MSEs are keen on borrowing money from the external financial market rather than internal financing to fund rapid development.

\subsection{Discussion}

It is evident that MSEs financing in China is associated with firm's characteristics, for example, industry, ownership, size, business scope, age of owners and their educational qualification. Meanwhile conventional theories including pecking order, trade-off and bootstrap arguments, do not seem to be adequate to explain what we have observed. For instance, Mayers (1984) suggests that the "average debt ratio will vary from industry-to-industry, because asset risk, asset type and requirements for external funds also vary by industry". Also the trade-off hypothesis says, businesses with mostly tangible assets would borrow more since more collateral could be provided by their assets (Jordan et al., 1998; Michaelas et al., 1999). Nevertheless these may be identified by the business type, owner's age and education.

Emerged from our results, those MSEs with creative business, and with owner/mangers aged between 30 and 49, who have gained more business experiences, and higher education qualification with better financial market knowledge are likely to receive more external fund in China. Approaches to MSEs financing is indeed to capture the financing development, in particular, the neglects of human capitals. As a result, the model of Cassar and Holmes (2003) should capsule human capitals denoted as HUMAN in equation 2.

$$
\mathrm{Y}=\beta_{0}+\beta_{1} S I Z E+\beta_{2} N O N A+\beta_{3} R O A+\beta_{4} R I S K+\beta_{5} G R O W+\beta_{6} H U M A N
$$

\section{Conclusion}

This paper has addressed the issue of MSEs' financing in China through investigating financial policy, banking and funding options, and MSEs' preferences. Results confirm that the financial needs and options of Chinese MSEs vary with stages of the business cycle. At start-up, MSEs tend to raise funds from the owner's personal savings and the savings of immediate families and friends. In the next episode of expansion, MSEs have strong financial needs indeed and gain access to intermediated finance such as bank loans. Our findings provide substantial support for the pecking order theory and the financial growth cycle model.

Moreover, the proportion of small businesses using bank loans is still not as high as we 
expected, which is less than 20\%. The most important factors influencing Chinese lenders when they issue loans to MSEs are still critical, including secured property, taxation submission, national finance policies, accounting document and credit scoring. Although Chinese authorities has improved the environment of MSEs financing improved since the late 1990s, the associations between MSEs and banks have not been tightened. This alerts policy makers for the need to re-examine the current credit guarantee institutional and effective scheme in China. Surprisingly, our results highlight that owner or mangers who are from 30 to 49 years old, with greater levels of business experiences, higher education background, and better knowledge of the financial market, would like to seek external financial resources and thus are more likely to receive external fund. So that the MSEs financing model should add human capitals as an important determinant.

Future studies may extend to larger samples with longer time range, and more sophisticated model is in needed of development. Apart from the capital structures, other variables that are relevant to output growth should be discussed. Empirical studies could carry on to test both financing and growth hypotheses, and therefore the research outcomes would contribute to expanding the body of knowledge about MSEs financing in China.

\section{Acknowledgement}

This work was supported by cultivation and innovation programs of the institute for enterprise development, Jinan University (No. 2013CP003). Also thanks are due to seminars and conferences participants for their valuable comments. The usual caveat applies.

\section{References}

Ang, J. S. (1991). Small Business Uniqueness and the Theory of Financial Management. Journal of Small Business Finance. 1(1). 1-13. http://jefsite.org/RePEc/pep/journl/jef-1991-01-1-b-ang.pdf

Ayyagari, M. Beck, T., \& Demirgüç-Kunt, A. (2006). Small and medium enterprises across the globe : a new database Policy Research Working Papers No. WPS 3127. http://documents.worldbank.org/curated/en/2003/08/2511638/small-medium-enterprises-acro ss-globe-new-database\#

Barton, S. L. Gordon, P. I. (1987). Corporate Strategy: Useful Perspective for the Study of Capital Structure? Academy of Management Review. 12(1). 67-75. http://dx.doi.org/10.5465/AMR.1987.4306479

Beck, T. Demirgüç-Kunt, A., \& Maksimovic, V. (2003). Financial and Legal Institutions and Firm Size. Policy Research Working Papers. http://dx.doi.org/10.1596/1813-9450-2997

Berger, A. N. Udell, G. F. (1998). The economics of small business finance: The roles of private equity and debt markets in the financial growth cycle. Journal of Banking \& Finance. 22(6-8). 613-673. http://dx.doi.org/10.1016/S0378-4266(98)00038-7

Cassar, G. Holmes, S. (2003). Capital structure and financing of SMEs: Australian evidence. Accounting \& Finance, 43(2). 123-147. http://dx.doi.org/10.1111/1467-629X.t01-1-00085 


\section{Macrothink}

Business and Economic Research ISSN 2162-4860 2016, Vol. 6, No. 1

CHFS. (2014). Chinese Micro and Small Enterprises Development Report 2014. Chendu: Southwestern University of Finance and Economics

Chittenden, F. Hall, G., \& Hutchinson, P. (1996). Small firm growth, access to capital markets and financial structure: Review of issues and an empirical investigation. Small Business Economics. 8(1). 59-67. http://dx.doi.org/10.1007/BF00391976

Cosh, A. Hughes, A. (1994). Size, financial structure and profitability: UK companies in the 1980's. In A. Hughes \& D. J. Storey (Eds.), Finance and the Small Firm (pp. 18-63). London: Routledge.

Cousin, V. (2011). Banking in China. (2nd ed.). London: Palgrave Macmillan. http://dx.doi.org/10.1057/9780230306967

Dollinger, M. J. ( 2002). Entrepreneurship: Strategies And Resources. (3rd ed.): Prentice Hall.

Fluck, Z. Holtz-Eakin, D., \& Rosen, H. S. (1998). Where Does the Money Come From? The Financing of Small Entrepreneurial Enterprises: New York University, Leonard N. Stern School Finance Department Working Paper Seires 01/1998.

Homaifar, G. Zietz, J., \& Benkato, O. (1994). An empirical mode of capital structure: some new evidence. Journal of Business Finance \& Accounting. 21(1). 1-14. http://dx.doi.org/10.1111/j.1468-5957.1994.tb00302.x

Jones, R. G. (1979). Analyzing initial and growth financing for small business. Management Accounting. 61(5). 30-38.

Jordan, J. Lowe, J., \& Taylor, P. (1998). Strategy and Financial Policy in UK Small Firms. Journal of Business Finance \& Accounting. 25(1-2). 1-27.

http://dx.doi.org/10.1111/1468-5957.00176

Kempson, H. E. Whyley, C. M. (1999). Kept out or opted out? Understanding and combating financial exclusion. (iv ed.): Joseph Rowntree Foundation.

Kimhi, A. (1997). Intergenerational succession in small family businesses: borrowing constraints and optimal timing of succession. Small Business Economics. 9(4). 309-318. http://dx.doi.org/10.1023/A:1007987731337

Michaelas, N. Chittenden, F., \& Poutziouris, P. (1999). Financial Policy and Capital Structure Choice in U.K. SMEs: Empirical Evidence from Company Panel Data. Small Business Economics. 12(2). 113-130. http://www.jstor.org/stable/40229004

Myers, S. C. (1984). The Capital Structure Puzzle. The Journal of Finance. 39(3). 574-592. http://dx.doi.org/10.1111/j.1540-6261.1984.tb03646.x

Norton, E. (1990). Similarities and differences in small and large corporation beliefs about capital structure policy. Small Business Economics. 2(3). 229-245.

http://dx.doi.org/10.1007/BF00389531

Norton, E. (1991). Captial structure and small public firm. Journal of Business Venturing. 
6(4). 287-303. http://dx.doi.org/10.1016/0883-9026(91)90020-E

Osteryoung, J. Constand, R. (1992). Financial ratios in large public and small private firms. Journal of Small Business Management. 30(3). 35-46.

Park, A. Sehrt, K. (2001). Tests of Financial Intermediation and Banking Reform in China. Journal of Comparative Economics. 29(4). 608-644.

http://dx.doi.org/10.1006/jcec.2001.1740

Podpiera, R. (2006). Progress in China's Banking Sector Reform: Has Bank Behavior Changed? : IMF Working Paper No. 06/71

Poutziouris, P. Chittenden, F. (1996). Family Businesses or Business Families ? Leeds: Institute for Small Business Affairs.

Poutziouris, P. Wang, Y., \& Chan, S. (2002). Chinese entrepreneurship: the development of small family firms in China. Journal of Small Business and Enterprise Development. 9(4). 383-399. http://www.emeraldinsight.com/doi/abs/10.1108/14626000210450568

Terpstra, D. E. Olson, P. D. (1993). Entrepreneurial start-up and growth: a classification of problems. Entrepreneurship Theory and Practice. 17(3). 5-15.

Titman, S. Wessels, R. (1988). The Determinants of Capital Structure Choice. The Journal of Finance. 43(1). 1-19. http://dx.doi.org/10.2307/2328319

VanAuken, H. E. Neeley, L. (1996). Evidence of Bootstrap Financing among Small Start-Up Firms. Journal of Entrepreneurial and Small Business Finance. 5(3). 235-249.

http://digitalcommons.pepperdine.edu/jef/vol5/iss3/4

Wald, J. K. (1999). How firm characteristics affect capital structure: an international comparison. Journal of Financial Research. 22(2). 161-187.

http://dx.doi.org/10.1111/j.1475-6803.1999.tb00721.x

Wang, Y. (2004). Impact of the WTO on commercial banks and their response. Suzhou Education College Paper. 7(4). 16-19.

\section{Copyright Disclaimer}

Copyright for this article is retained by the author(s), with first publication rights granted to the journal.

This is an open-access article distributed under the terms and conditions of the Creative Commons Attribution license (http://creativecommons.org/licenses/by/3.0/). 